\title{
Información y Novedades
}

\section{EVENTOS}

- Reunión Anual de Biología Experimental (American Association of Anatomists): Boston, USA, 20 al 24 de abril de 2013. www.anatomy.org

- $\quad 41^{\text {a }}$ Reunión Anual de la Anatomical Society of Southern Africa: Durban, South Africa, 20 al 24 de abril de 2013. www.assa2013.ukzn.ac.za

- $5^{\circ}$ Simposio Internacional de Anatomía Clínica y Aplicada y Primer Encuentro Paneuropeo de Anatomistas: Graz, Austria, 24 al 26 de mayo de 2013. (Ver a continuación para mayor información)

- $\quad 12^{\circ}$ Congreso de la Asociación Europea de Anatomía Clínica: Lisboa, Portugal, 26 al 29 de junio de 2013 (Ver a continuación para mayor información)

- $30^{a}$ Sesión Científica Anual (American Association of Clinical Anatomy): Denver, Colorado, USA, 9 al 13 de julio de 2013. www.aacameeting.wildapricot.org

- $\quad 26^{\circ}$ Congreso de la Sociedad Anatómica Española: Fuerteventura, Islas Canarias, España, 5 al 7 de setiembre de 2013 .

- XXIII Simposio Internacional de Ciencias Morfológicas: Nigata, Japón, 10 al 13 de setiembre de 2013. www.isms2013.jp

- $67^{\circ}$ Congreso Nacional de la Italian Association of Anatomy and Histology: Brescia, Italia, 20 al 22 de setiembre de 2013. www.societaitalianadianatomia.unifi.it

- $\quad$ III Congreso Argentino de Anatomía Clínica: Mendoza, Argentina, 25 al 28 de setiembre de 2013.

- XVIII Congreso Panamericano de Anatomía: Huatulco, Oaxaca, México, 29 de setiembre al 4 de octubre de 2013 (Ver a continuación para mayor información)

- $\quad 1^{\circ}$ Congreso de la Federación Internacional de Asociaciones de Anatomistas (IFAA): Beijing, China, 8 al 10 de agosto de 2014. 


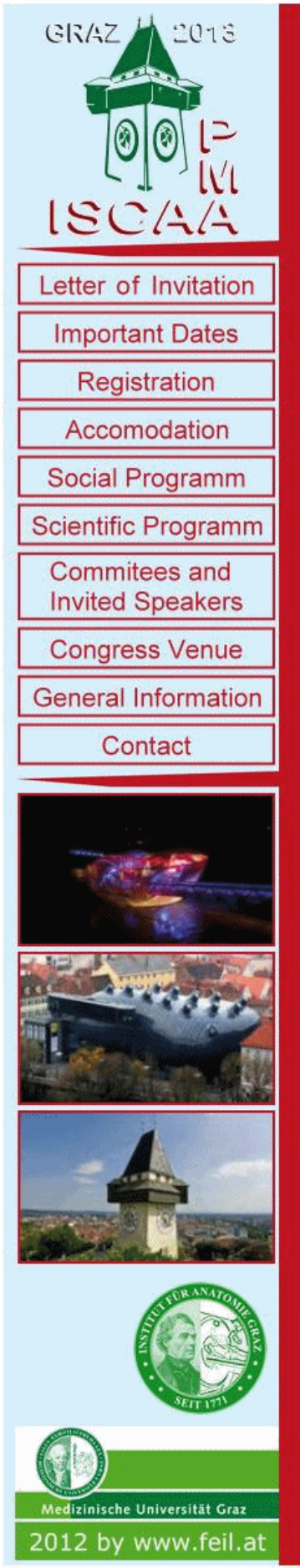

\section{5th International Symposion of Clinical and Applied Anatomy}

\section{1st Paneuropean Meeting of Anatomists}

Dear colleagues, participants, guests and friends,

On behalf of the organizing team of the Institute of Anatomy, I am, as Congress President, proud to invite you to the 5th International Symposium of Clinical and Applied Anatomy (ISCAA) and the 1st Paneuropean Meeting for Anatomists (PAM) in Graz from 24th to 26th May 2013. The meetings are held at the Institute of Anatomy at the Medical University of Graz, an institute which is focused on macroscopical and clinical anatomy and well known internationally.

The 5th ISCAA meeting is a very good opportunity for young anatomists to get first experiences in presentations of posters or lectures. The first steps into the scientific field are very important for all of us and especially young scientists to improve future publications and teaching. It should be an opportunity for young anatomists to meet experienced ones and will hopefully be full of high quality contributions and fruitful discussions. Many topics are an opportunity for all anatomists to submit abstracts and to come to Graz to present their scientific results.

The 1st PAM represents a revitalization of the original "Alpenländisches Anatomentreffen" which was held for the last time in Kötschach-Mauthen (Austria) in 1998. The meeting should be regarded as an invitation to Anatomists of all Europe and the entire World to build up and cultivate social and professional networks as well as friendships. Therefore, the social program is also that important but the scientific one. We hope that the symposium and meeting can be of great use of all participants in scientific and private field.

Therefore it is a great honor, to invite you to Graz, Austria, a small but beautiful city with Mediterranean and medieval ambience, a young city with several universities which waits to be explored by you.

We are looking forward seeing you in Graz,

oProf. Dr. med. univ. Dr. hc. Friedrich Anderhuber

Congress President

Head for Department of the Institute of Anatomy, Medical University of Graz

Graz, May 24th - 26th 2013

Institute of Anatomy

Harrachgasse 21/1

http://www.iscaa-pma-graz.at

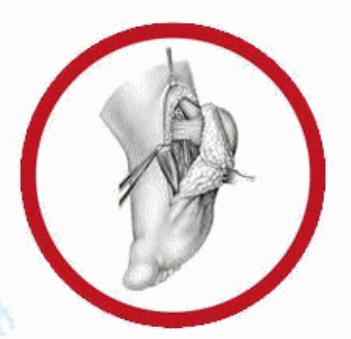




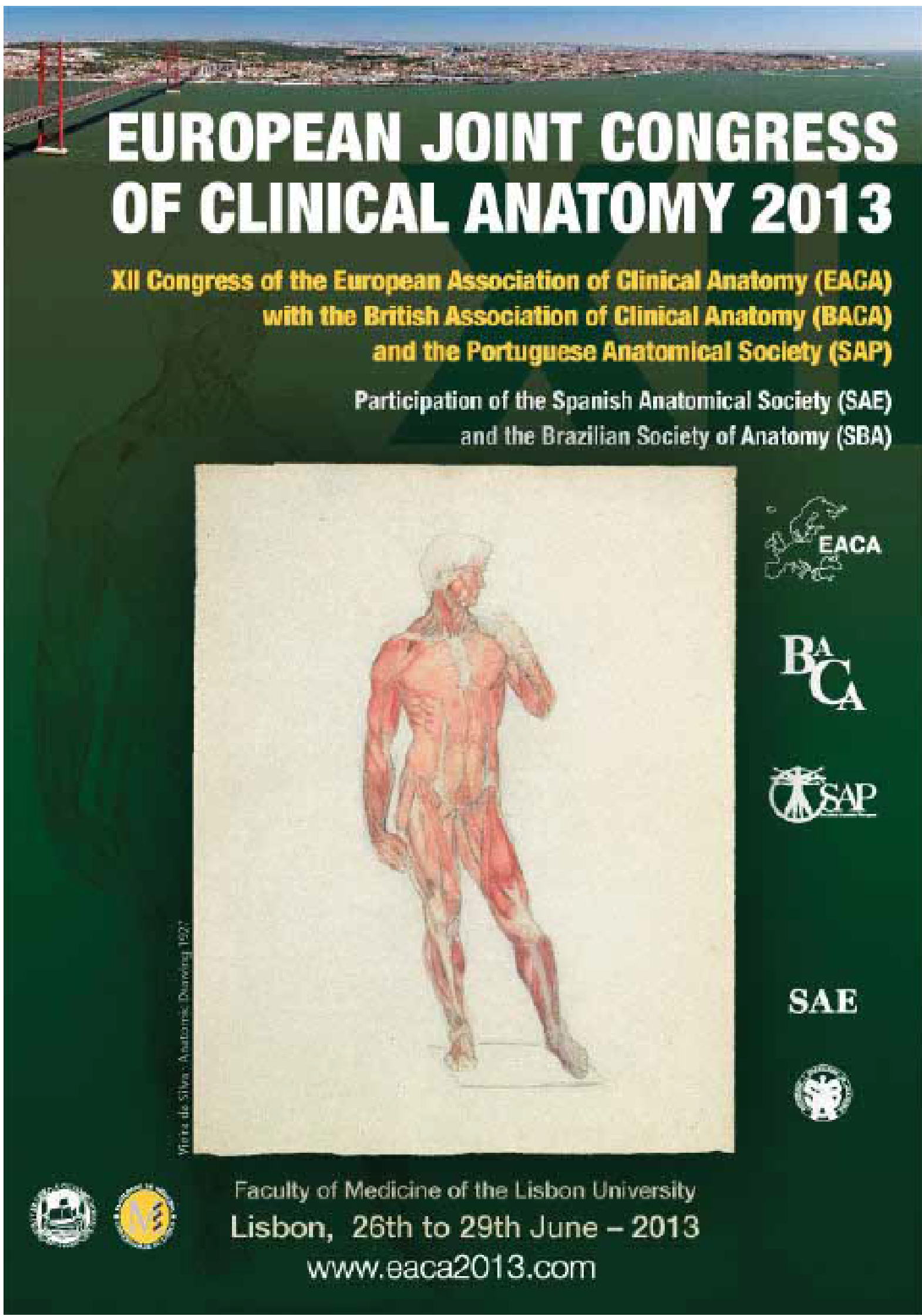




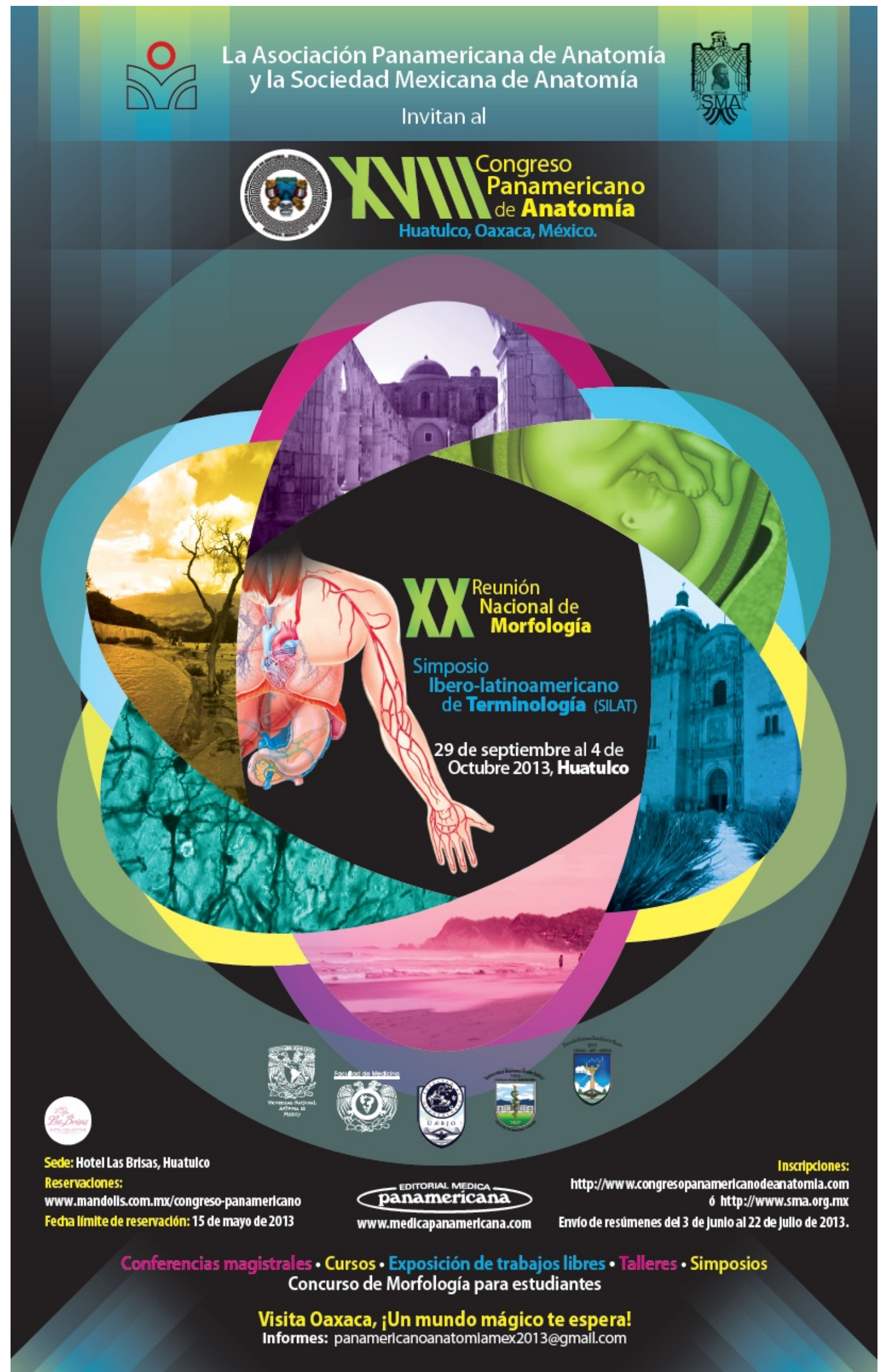

